\title{
Social and irrigation water management issues in some water user's associations of the Low Segura River Valley (Alicante, Spain)
}

\author{
H. M. Puerto Molina ${ }^{1}$, A. Melián Navarro ${ }^{2}$, \\ M. C. Rocamora Osorio ${ }^{1}$, A. Ruiz Canales ${ }^{1}$, J. M. Cámara Zapata ${ }^{3}$ \\ \& R. Abadía Sánchez ${ }^{1}$ \\ ${ }^{I}$ Department of Engineering, Miguel Hernandez University, Spain \\ ${ }^{2}$ Department of Agro-Environmental Economy, \\ Miguel Hernandez University, Spain \\ ${ }^{3}$ Department of Applied Physics, Miguel Hernandez University, Spain
}

\begin{abstract}
In the region of the Low Segura River Valley, in the southern area of the Alicante province, the reduction in irrigation water availability and the political debate draw a difficult situation for agriculture. During recent years, as a result of the application of the National Irrigation Plan, irrigated areas are being modernised, improving their irrigation network infrastructure. But, for modernisation to go beyond isolated or point measures, it should spread through all procedures that allow the Water User's Associations comprehensive management and control of irrigation water. The work presented here aims at analysing and quantifying the problems and needs perceived by some WUAs about irrigation. A survey was made by a 76 items questionnaire structured in four main topics: i) WUA identification and general information; ii) aspects related to decision making and management processes; iii) services for members provided by the WUA, and iv) future perspectives and improvement possibilities.
\end{abstract}

Keywords: WUA, water use, survey, irrigated agriculture, water availability.

\section{Introduction}

The Southern area of the province of Alicante, in which this work was made, corresponds to the region of the Low Segura River Valley that gathers 27 
municipalities with a total surface of $957 \mathrm{~km}^{2}$, and approximately $16 \%$ of the total area of the province [1].

The area cultivated in the region represents $24 \%$ of the total of the province's cultivated land taking into account both dry-land and irrigated cultures, though the irrigated surface means $40 \%$ of the total irrigated land of the province of Alicante [2]. Citrus is the main crop (24,317 ha) that represents $69 \%$ of the total of citrus cultivated in the province. Horticultural crops $(6,584$ ha) come in second place, $63 \%$ of the province's area of horticultural crops, and in third place are other fruit trees $(5,495 \mathrm{ha})$, that comprise, $13 \%$ of the province's total surface of other fruit trees [2]. In spite of the mild climate, the good quality of the soil and the suitable commercialization of agricultural products, Juárez [3] indicates that the limitation to the agricultural development of the area is a consequence of water shortages.

In this region, the irrigation water is administered by Water User's Associations (WUAs) some of which had their origins in the Middle Ages. A distinction among them, based on their origin and source of the irrigation water, is set up: the traditional WUAs take the irrigation water through a network of channels from the Segura river and all of them were established before 1933; the Water Transfer WUAs take the irrigation water from the Tagus-Segura water transfer and were settled down in the 70' and up till the end of the 90' of the 20th century. The WUA constitutes a group that self-manages freely, and that, as far as regards trusteeship, generally does not receive much support from the Public Administration. A fundamental aspect for a good operational management of the WUA is obtaining information relative to water management [4].

The problems of the WUAs are those of irrigated agriculture. The modernization of irrigation is mainly understood as the improvement of its infrastructures, and although it consists mainly in pressurizing water supplies up to the plot intake and other services, it is not only that. The modernization concept must extend, in agreement with Sanz and Ursua [5], the frame of isolated or point improvements, including all the achievements that allow the WUAs a management and integral control of the water in their irrigated areas. In the particular case of the WUA "Riegos de Levante" (Alicante) and according to Llanes [6] the modernization of irrigation infrastructures aims not only at the installation of a pressurized irrigation network that could allow drip irrigation, but "at improving the management of the irrigated land, at optimizing the distribution and use of water, helping its saving and the adaptation of the crops to the new technologies" aim that perhaps is more related to water management on the part of the WUA and, finally of the members. Other aspects must be taken into account in the analysis of the function of the WUAs as the influence of the land urbanization and the changes of rural society [7], the changes in the land uses and the reorientation of crops on a rent basis.

If agricultural farms are undergoing significant changes related to generational replacement, reduction in the number of farms and consequently increase of their average size, reorientation of crops, etc., the WUA must be prepared for these changes, and the technical training of the farmers is going to play a very important role to get adapted to the new scenario. The irrigation 
advisory services facilitate this adaptation as long as they support the farmer and give irrigation recommendations that help to carrying out a sounder use of water.

In recent years, there is a great debate in this region, as a result of the alternatives given to the National Hydrological Plan and drought conditions that have significantly reduced the irrigation water availability of the WUAs. In this framework, this work has the aim of analysing and quantitatively describing the problems and requirements about irrigation perceived by the WUAs of the region of the Low Segura River Valley (Alicante).

\section{Methodology}

The survey is a method to collect ideas, opinions, and expectations, normally answering a questionnaire or by means of an interview, and is suitable when the information must come directly from the concerned people. In the evaluation of social and technical aspects relative to irrigated land operations, the survey to farmers has successfully been used in our country by Alvarez et al. [8], Neira et al. [9] and Cuesta et al. [10]. Also Tanaka and Sato [7] analyze the behaviour in irrigation water management of Japanese WUAs by means of surveys to presidents and personnel of the WUAs.

Table 1: Number of hectares for each irrigation type and water-transfer zone.

\begin{tabular}{|l|c|c|c|c|c|c|c|}
\hline \multicolumn{1}{|c|}{ Type } & Zone & $\begin{array}{c}\text { Total } \\
\text { number } \\
\text { of } \\
\text { WUAs } \\
\text { Turveyed } \\
\text { WUAs }\end{array}$ & $\begin{array}{c}\text { Number } \\
\text { su of } \\
\text { surveyed } \\
\text { WUAs }\end{array}$ & $\begin{array}{c}\text { Total } \\
\text { irrigated } \\
\text { area (ha) }\end{array}$ & $\begin{array}{c}\text { Irrigated } \\
\text { area of the } \\
\text { surveyed } \\
\text { WUAs } \\
\text { (ha) }\end{array}$ & $\begin{array}{c}\% \text { of } \\
\text { irrigated } \\
\text { area } \\
\text { surveyed }\end{array}$ \\
\hline Traditional & $\begin{array}{c}\text { Levante } \\
\text { R.M. }\end{array}$ & 14 & 8 & $57.1 \%$ & & $\left(^{*}\right)$ & \\
\hline $\begin{array}{l}\text { Traditional } \\
\text { Transfer }\end{array}$ & $\begin{array}{c}\text { Riegos } \\
\text { Levante } \\
\text { L.M. }\end{array}$ & 15 & 7 & $46.7 \%$ & 36,751 & 35,448 & $96.5 \%$ \\
\hline $\begin{array}{l}\text { Water } \\
\text { Transfer } \\
\text { de }\end{array}$ & $\begin{array}{c}\text { Saladares } \\
\text { Alicante }\end{array}$ & 1 & 1 & $100 \%$ & 3,993 & 3,993 & $100 \%$ \\
\hline $\begin{array}{l}\text { Water } \\
\text { Transfer }\end{array}$ & $\begin{array}{c}\text { Pedrera } \\
\text { Zone }\end{array}$ & 14 & 9 & $64.3 \%$ & 11,565 & 8,603 & $74.5 \%$ \\
\hline & \multicolumn{1}{|c|}{14} & 45 & 25 & & 53,809 & 49,544 & $92 \%$ \\
\hline
\end{tabular}

(*) Without data.

Surveys were administered to each WUA, interviewing personally the president, secretary or the person designated by them, during the period of July to September 2005. Altogether 25 surveys have been made out of 45 possible 
ones. One first classification of the WUAs has been established (table 1) based on their belonging to the traditional irrigated land ( 9 of the surveyed ones) or irrigating from the Tagus-Segura water transfer (14), and also taking care of the irrigated area, establishing four zones: "Riegos de Levante Margen Derecha" (Right margin, RM), "Riegos de Levante Margen Izquierda" (Left Margin, LM), "Saladares de Alicante" (Alicante's salty marshes) and the "Pedrera" Zone. The importance of the surveyed WUAs can be seen in table 1 since the percentage of surveyed WUAs represents more than half of the total number, and it includes $92 \%$ of the total surface irrigated by the water transfer in the region.

The previous design of the questionnaire and passes to test WUAs took place in June 2005. The definitive questionnaire contains a total of 76 questions structured in four main blocks. The first one ( 7 questions) asks for the identification of the WUA, as well as general information about it, in aspects related to the settlement year, kind of services available to the farmers, etc. In the second one questions are posed on the decision making process and management related aspect (17 questions). The third block is related to the WUAs's services to the partners, and especially about access to training courses (5 questions); the fourth block deals with future perspectives (8 questions) and improvement possibilities (39 questions).

\section{Results and discussion}

\subsection{Block I: WUA's general information}

The survey began with the identification of the surveyed WUA, the year of settlement was asked emphasizing the distinction between the traditional ones like the oldest Water Court of Orihuela dating from 1275. One dated from the 15 th century, another one the 16th century, two of the 18th and two from the 19 th centuries. In some cases there is a reference to the date of the decrees, but for those older ones it has not been possible to determine exactly their age. About the WUAs that irrigate from the water transfer, the oldest ones were established in 1930 General Water User's Association "Riegos de Levante Margen Izquierda" (Left Margin) and the youngest one in 1998 (Water User's Association of Albatera), stemming from the previous one.

The interviewed people have declared almost unanimously (96\%), that the service that the WUA renders to its partners is providing irrigation water, and only one out of the 25 provides also water for urban supply. Regarding the type of water concession, all of them have superficial water and $4 \%$ have an additional concession of regenerated waste-water.

Regarding the establishment of charges, the WUAs that irrigate from the water transfer, (16 of the WUAs interviewed), the majority (44\%), establish their rates on a volume basis, 4 WUAs that represent $25 \%$ of the surveyed ones, establish the rate according to the irrigation surface, and $3.2 \%$, according to the irrigation time, two WUAs chose other types of charging: in one of them all pay the same amount and the second one does not answer. Nevertheless in traditional WUAs ( 9 of the WUAs interviewed), none of the surveyed ones establishes their 
rates on a volume or irrigation time basis, 3 have responded that according to the irrigated surface, and the other 6 chose other types: three of them responded that there is no rate, two of them pay quotas for channel maintenance and another one that they irrigate when water is running in the channel.

It is very important for the normal operation of the WUA that the partners feel integrated into it and that they have facilities in order to have their meetings. 23 Communities have social centre $(92 \%)$, and 18 of them $(72 \%)$ have their own premises where to meet, 6 Associations do not have their own premises and one of the surveyed ones did not respond to the question. Those Associations that do not have their own premises were asked if having them could influence positively the management and benefit the services to the partners. Half of them answered no, two said it would and to another one it was indifferent.

\subsection{Block II: management and decision making}

This block of questions dealt with aspects relative to the regularity of the assemblies, renovation of the Board of directors, age of the president, number and age of the partners, etc. As far as the frequency whereupon they meet in assembly a majority (60\%), have only one general assembly per year, the percentage being greater in those WUAs that irrigate from the water transfer (68.8\%). 20\%, 5 associations, meet twice a year, and two associations, one traditional one and another one irrigating from the water transfer, have monthly meetings. It is remarkable the disparity among the associations that responded "other", all of them of traditional irrigation, from one assembly each three years to another one with two meetings weekly which means more than 100 per year, this one corresponds to the Water Court of Orihuela, one of the greater ones; although in this case the assemblies are probably made grouped in secondary channels.

The question about the age of the president reveals an already little participation of the young people devoted to management tasks in the WUAs, this being a common characteristic of Spanish agriculture. Therefore, out of the validated answers (one association did not answer), $75 \%$ of the presidents are above the age of 50 years, most of these (40\%) surpass 65 years of age, and only two communities have a younger president (40 years or less). Regarding the time the president dedicates to the management of the association's activity, it is usually more than 4 hours a week, while in associations that irrigate from the water transfer it is mainly between 4 and 10 hours (10 WUAs out of 16 chose this answer), and in those of traditional associations affirm that they dedicate some more than 10 hours a week ( 3 WUAs out of 7 validated answers).

The Board of directors, integrated by the president and other members of the society, meets regularly to deliberate and to coordinate aspects of interest in the functioning of the WUA. These periodical meetings usually take place once a month or less in the WUAs that irrigate from the water transfer, being very uncommon the WUAs that have two or three meetings a month and only one claims to meet more than four times. In the traditional WUAs two groups are observed, those that have one meeting a month or less and those that state that 
they meet 2 or 3 times a month (even two of them meet more than four times). This second group agrees with the WUAs which claimed a greater time of dedication of the president to the management tasks.

Some resistance to change is observed regarding the renovation of the Board of directors' members. In most of the WUAs the position is appointed for at least 4 years, and this is so mainly in those that irrigate from the water transfer, almost $70 \%$. On the contrary, in traditional WUAs the renovation of the Board usually takes place every two or three years. In these associations it is frequent to have a partial renovation of members, so that every year or at least every other year there are elections, but only to elect half of its members. This way gives some continuity to the association's projects and there is also an adaptation period that does not interrupt the on-going management.

All the traditional WUAs surveyed (9) have more than 200 members. Four of them $(44.4 \%)$, oscillate between 200 and 1,000 and five $(55.6 \%)$ have more than 1,000 members, the biggest one having 9,000 members. In those WUAs that irrigate from the water transfer (16), the number of members is smaller since only half of them have more than 200 members, of which six $(37.5 \%)$ have between 200 and 1,000, and the rest more than 1,000 (one has 1,300 and the greater one than is "Riegos de Levante" LM that has 20,000).

It is interesting to know the degree of dedication of these members to the agricultural activity, mainly if this dedication is full-time or part-time. Part-time farmers complement the agricultural income with another activity and in some cases the main income of the familiar unit does not even come from the agricultural activity. For traditional WUAs, the part-time percentage of partners is $84 \%$, whereas in those that irrigate from the water transfer is $64.5 \%$, indicating that the water transfer farmers tend to have agriculture as their main business.

Asking about the average age of the members revealed that the majority $(68 \%)$ of members are in the age interval of 40 to 60 years, being this percentage higher in WUAs that irrigate from the water transfer $(81.3 \%)$. In traditional WUAs, out of 7 valid answers (2 associations did not answer) the majority (57\%) are between 40 and 60 years old. No WUA chose the option less than 40 years.

A problem showed by Spanish agriculture is population aging. WUAs were asked if there were partners that could be eligible as "young farmers" (Law $19 / 95$, of July 4th, of Modernization of agricultural farms), $92 \%$ of the cases (22 WUAs) answered yes, one WUA responded no and another one did not answer. Although the existence of young farmers is remarkable, they do not represent a generational replacement since only $18.2 \%$ of the WUAs that responded affirmatively indicated that in their associations there were more than 10 "young farmers".

A significant detail on the social distribution is the fact that although in most of the WUAs women take part as partners, (22 WUAs (88\%) answered yes, one (4\%) answered no, and two WUAs did not answer to the question about having women among the WUAs members) its representativeness in management is much reduced. Only 4 WUAs $(18 \%$ of the affirmative answers to the previous question) indicated that they have a woman as a member of the Board of 
directors (two women in one WUA and one woman in the other three), which confirms the low feminine participation in management and representation in these societies. Differences between the traditional WUAs and those that irrigate from the water transfer have not been appraised on this issue.

\subsection{Block III: Training and services to members}

With regard to the interest and the importance allowed to training, overall most of the WUAs consider the training of members to be important or very important (76\%). Training is more appreciated by the WUAs that irrigate from the water transfer, since $75 \%$ of these consider training to be quite important and $12.5 \%$ very important (though the only WUA that affirmed that training was not important at all belongs also to this group). Traditional irrigation WUAs were more cautious: one did not answer while for one of the eight WUAs that answered the question (11.1\%) training was very important, four of them $(50 \%)$ claimed it to be quite important and three of them (38\%), indicated that it was barely important.

In order to deepen in the aspects related to training, WUAs were asked on the number of training courses that they had organized in last two years, since this would be an actual indicator of the degree of importance given to training. So we observed (table 2) that only five WUAs have organized at least one course. These five correspond in two cases with those which stated that training was very important, in other two with those which thought that it was quite important and finally with the WUA which did not show its opinion about its importance.

The contents of these courses have dealt on agricultural subjects, pesticides management and modernization in irrigation. As far as the short term forecast for the organization of courses, those WUAs that have already organized courses (four) are going to continue and have programmed some others for the next years, whereas the rest have not planned the organization of any course. A course on prevention of labour risks is proposed for the next years, in addition to those about pesticides and other agricultural subjects.

Table 2: Organization of training courses.

\begin{tabular}{|l|c|c|c|c|c|r|r|}
\hline $\begin{array}{c}\text { Importance of } \\
\text { training }\end{array}$ & $\begin{array}{c}\text { Courses } \\
\text { organized }\end{array}$ & $\begin{array}{c}\text { Traditiona } \\
1\end{array}$ & $\%$ & $\begin{array}{c}\text { Water } \\
\text { Transfer }\end{array}$ & $\%$ & $\begin{array}{c}\text { Tota } \\
1\end{array}$ & $\%$ \\
\hline Very important & No & & $0 \%$ & 1 & $6.25 \%$ & 1 & $4 \%$ \\
\cline { 2 - 8 } & Yes & 1 & $11.1 \%$ & 1 & $6.25 \%$ & 2 & $8 \%$ \\
\hline \multirow{2}{*}{ Quite important } & No & 2 & $22.2 \%$ & 10 & $62.5 \%$ & 12 & $48 \%$ \\
\cline { 2 - 8 } & Yes & 1 & $11.1 \%$ & 1 & $6.25 \%$ & 2 & $8 \%$ \\
\cline { 2 - 8 } & Blank & 1 & $11.1 \%$ & 1 & $6.25 \%$ & 2 & $8 \%$ \\
\hline Unimportant & No & 3 & $33.3 \%$ & 1 & $6.25 \%$ & 4 & $16 \%$ \\
\hline Not important & No & & $0 \%$ & 1 & $6.25 \%$ & 1 & $4 \%$ \\
\hline No answer & Yes & 1 & $11.1 \%$ & & $0 \%$ & 1 & $4 \%$ \\
\hline
\end{tabular}

In view of the results in table 2 , most $(67 \%)$ of the WUAs that claimed training being very important have acted accordingly organizing some training courses, while only $13 \%$ two of the ones which considered that it was quite 
important did organize any course. As it could be expected, none of the WUAs giving little or no importance to training has scheduled any course in the last two years.

\subsection{Block IV: Future perspectives and improvement possibilities}

In the block of future perspectives, WUAs were asked about their opinion on the functioning of the association, level of satisfaction and how they envisage the future.

When asked about how they foresee the future of the WUA, the majority (84\%) answered "uncertain", only one sees it "good" (4\%), whereas another one sees it "difficult" (4\%). No one responded "promising". One WUA did not answer, another one responded "others", indicating that the tourism will reduce the importance of the WUAs' problems.

The level of satisfaction with the functioning of the WUA is high, since six of the 25 surveyed WUAs responded that they are very satisfied (24\%), 17 are satisfied (68\%), whereas two did not answer (8\%). Concerning the aspects that could be improved, the questionnaire presented the option to answer among several alternatives: management, information, services to the partners and others, being it possible to mark more than one option. The results of the 25 WUAs (table 3), reveal that five of them did not answer and the rest thinks that mainly the information system must improve (4 WUAs), the services to the partners (3 WUAs), the quality of the water or its amount (3 WUAs), the management ( 2 WUAs), the management and the services to the members (1 WUA), the infrastructures (2 WUAs) (dams, irrigation systems), the increase of prices for the growers (1 WUA) and 4 WUAs said that everything should be improved.

Almost all the surveyed WUAs (96\%) agree in pointing at water availability or quality as the most important problem of the WUA, and only one aims at the city-planning or urban development problem.

Table 3: $\quad$ Issues to be improved in the WUA.

\begin{tabular}{|l|c|r|}
\hline Issues to improve & WUAs & \multicolumn{1}{c|}{$\%$} \\
\hline Management & 2 & $8 \%$ \\
\hline Services to the partners & 3 & $12 \%$ \\
\hline Management and services to the members & 1 & $4 \%$ \\
\hline Information & 4 & $16 \%$ \\
\hline Infrastructures & 2 & $8 \%$ \\
\hline Water amount and quality & 3 & $12 \%$ \\
\hline All the former & 4 & $16 \%$ \\
\hline Others: Increase of prices to the growers & 1 & $4 \%$ \\
\hline No answer & 5 & $20 \%$ \\
\hline Total WUAs & 25 & $100 \%$ \\
\hline
\end{tabular}


Among the solutions to improve the availability of water they emphasize water transfers with 17 answers (68\%), followed by the sewage treatment plants with five $(20 \%)$, whereas three WUAs did not respond $(12 \%)$. Those that point out the sewage treatment plants as the best alternative think that the water transfer causes a great environmental impact (this was the answer of a traditional irrigation WUA), and that the water desalination plants are expensive (this was the opinion of water transfer WUAs), although also they show that the three alternatives are valid if water availability increases, or when political tendencies and reasons advise against other options. The WUAs that chose water transfers point out water quality and its price: the water from water transfer is cheaper and of better quality, the cost of the desalination plants is very high. The WUAs that did not show preference for any option think that a combination of the three options would be the best solution.

The Water Framework Directive (Directive 2000/60/EC, of October $23^{\text {rd }}$ ) appeals for full cost recovery, thus WUAs were asked about the price that the partners could pay for the water coming from a water transfer or from desalination plants. Most of them did not answer, and only five traditional WUAs pointed out that the water should have no cost for the growers or have a very low political price. As for the WUAs that irrigate from the water transfer, the participation was higher, ten WUAs answered, and they mainly pleaded the maintenance of current prices or that water should have a political price.

\section{Conclusions}

The WUAs surveyed indicate that their work is dedicated mainly to the management of irrigation water. The greater concern is detected on the quality of irrigation water and its availability. The problem of water shortages has been pointed out by all the people interviewed. Also a rather high satisfaction level with the functioning of the WUAs has been expressed. A reduced generational replacement has been detected, since although there are young farmers in the associations, their percentage on the total number of members is very low. The reduced presence of women as members and sometimes as members of the management boards has also been pointed out. It emphasizes the small relevance allowed to the training of farmers since there are very few WUAs that provide training courses, being this one a basic tool to improve the on-farm management of irrigation water. Regarding the alternatives to increase available water, farmers are more interested in water transfers than in desalinating plants, although in both cases they would not assume the real cost of water, but a political price.

\section{Acknowledgement}

This work was carried out as a part of the research project Efficient water and energy use in drip irrigation systems of the southern regions of Alicante province (GV05/087) financed by the "Conselleria d'Empresa, Universitat i Ciència" of the Generalitat Valenciana. 


\section{References}

[1] MAPA, 2005. Anuario de Estadística Agraria 2004. Misterio de Agricultura Pesca y Alimentación. Madrid.

[2] IVE, 2005. Instituto Valenciano de Estadística. Anuario de Estadística Municipal y Comarcal. Generalitat Valenciana. Valencia. http:www.ive.es

[3] Juárez, C. 2004. Asignación de recursos de agua para uso agrario y crecimiento económico en la comarca meridional agraria de Alicante. Revista de Estudios Agrosociales y Pesqueros, 202: 135-166.

[4] Mazón, J.J., Carazo, C. 2003. Estudio de una Comunidad de Regantes. Análisis de problemas y alternativas en la C.R. del Bajo Carrión (Palencia). CD de actas del XXI Congreso Nacional de Riegos. MéridaBadajoz 6 al 8 de mayo de 2005.

[5] Sanz, A., Ursúa, C. 2003. La modernización de regadíos y sus implicaciones ambientales: oportunidades para una gestión más sostenible. CD de actas del XXI Congreso Nacional de Riegos. MéridaBadajoz 6 al 8 de mayo de 2005.

[6] Llanes Ribas, R. 2005. La modernización de los regadíos de la Comunidad General de Regantes Riegos de Levante (Margen Izquierda del Segura). CD de actas del XXIII Congreso Nacional de Riegos. ElcheAlicante 14 al 16 de junio de 2005.

[7] Tanaka, Y., Sato, Y. 2005. Farmers managed irrigation districts in Japan: Assessing how fairness may contribute to sustainability. Agric. Water Manage. 77: 196-209.

[8] Álvarez, C.J., Cancela, J.J., Fandiño, M. 2005. Characterization of Irrigated Holdings in the Terra Chá Region of Spain: A first Step Towards a Water Management Model. Water Resour. Manage. 19: 23-36.

[9] Neira, X.X., Álvarez, C.J., Cuesta, T.S., Cancela, J.J. (2005). Evaluation of water-use in traditional irrigation. An application to the Lemos Valley irrigation district, northwest of Spain. Agric. Water Manage. 75: 137-151.

[10] Cuesta, T.S., Cancela, J.J., Dafonte, J., Valcárcel, M. Neira, X.X. 2005. Social aspects influencing water management in the Lemos Valley irrigation district, Spain. Irrig. and Drain. 54: 125-133. 